\title{
ANALISIS FAKTOR PRODUKSI DAN KELAYAKAN USAHATANI CABE MERAH DI KELURAHAN SEI GOHONG KECAMATAN BUKIT BATU KOTA PALANGKA RAYA
}

\begin{abstract}
Rajudinnor ${ }^{1)}$
ABSTRACT

This study aimed to: $i)$ analyze the influence of factors of production to the level of farm production Red Chillies, ii) determine the feasibility of farming Red Chillies during one production process, research was conducted in the village of Bukit Batu subdistrict Sei Gohong city of Palangkaraya. Total sample of farmers as many as 30 farmers was taken by simple random sampling (Sample Random Sampling) from the total population of Red Pepper farmers as many as 60 farmers. The analytical tool to answer the first objective equation is used Cobb Douglas: $\boldsymbol{Y}=\boldsymbol{b} \boldsymbol{o} \boldsymbol{X}_{1} \boldsymbol{b}^{1} \boldsymbol{X}_{2} \boldsymbol{b}^{2} \boldsymbol{X}_{3} \boldsymbol{b}^{3} \boldsymbol{X}_{4} \boldsymbol{b}^{4} \boldsymbol{X}_{5} \boldsymbol{b}^{5}$ where $Y=$ production $(\mathrm{kg}), X_{1}=$ land area $(\mathrm{Ha}), X_{2}=$ Seed $(\mathrm{kg}), X_{3}=$ fertilizer $(\mathrm{kg}), X_{4}=$ pesticides (liter), $X_{5}=$ labor $(\mathrm{HOK})$, bo $=$ coefficient parameter. While the analytical tool used to answer the second goal used analysis Revenue Cost Ratio (RCR), which is the ratio between the total revenue with the total cost of production. If $R C R>1$ then farming is feasible to cultivate. The results showed that the factors of production land, seed, fertilizer, pesticides and labor simultan eously affect significantly against Red Chillies production in Sub Sei Gohong Bukit Batu subdistrict city of Palangka Raya. Value Fcount (97,513)> Ftable $(2,409)$. Partially influence of each factor of production to production Red Chillies with a confidence level of $95 \%$, the area of land with an elasticity of 0.329 (significant), seeds 0.150 (significant), fertilizer 0.314 (significant), pesticides 0.140 (significant), and labor-0.020 (not significant). The value of Revenue Cost Ratio of Red Chili farming is 3.2. It means that every production cost expense of $R p$ 1,000 will generate revenue of Rp 3,200, -. RCR> 1 means that Red Chilli farming in Kelurahan Sei Gohong District of Bukit Batu Kota Palangka Raya is feasible or profitable.
\end{abstract}

Key word: Feasibility, Production Factor, Red Chilli Farming

PENDAHULUAN

\section{Latar Belakang}

Indonesia sebagai negara dengan jumlah penduduk yang besar menghadapi tantangan yang sangat kompleks dalam memenuhi kebuuhan pangan penduduknya. Oleh karena itu kebijakan pemantapan ketahanan pangan menjadi isu sentral dalam pembangunan serta menjadi fokus utama dalam pembangunan pertanian. Peningkatan kebutuhan pangan seiring dengan peningkatan jumlah penduduk dan peningkatan kesempatan kerja bagi penduduk guna memperoleh pendapatan yang layak merupakan dua komponen utama dalam perwujudan ketahanan pangan nasional. 
Permasalahan utama dalam mewujudkan ketahanan pangan saat ini terkait dengan adanya fakta bahwa pertumbuhan permintaan pangan terjadi lebih cepat dari pertumbuhan penyediaannya. Hal ini berakibat harga pangan dalam negeri menjadi mahal sehingga mendorong dilakukannya impor pangan yang menguras devisa negara.

Upaya untuk penyediaan pangan dalam negeri harus dilakukan melalui upaya peningkatan produksi melalui program intensifikasi dan ekstensifikasi. Terkait dngan upaya peningkatan produksi pangan ini tentunya pelaku produksi dalam hal ini petani akan termotivasi melakukan kegiatan produksi pertanian manakala usahatani yang dilakukannya dapat memberikan keuntungan yang layak untuk meningkatkan pendapatan mereka.

Dalam melakukan kegiatan produksi pertanian diperlukan input atau faktor produksi seperti lahan, tenaga kerja, benih, pupuk, dan pestisida. Melalui pengelolaan usahatani (farm management)) yang baik yakni dengan mengkombinasikan semua faktor produksi tersebut dalam kegiatan usahatani menghasilkan produksi pertanian yang diinginkan.

Salah satu komoditi yang menjadi kebutuhan utama masyarakat Indonesia adalah Cabe Merah. Komoditi Cabe Merah memiliki volatilitas harga yang tnggi dan sulit untuk distabilkan karena daya tahan komoditi ini yang sangat rendah (mudah busuk).

Di Kalimantan Tengah komoditi Cabe Merah menjadi salah satu pemicu terjadinya inflasi. Hal ini salah satunya disebabkan oleh ketidak seimbangan antara persediaan (supply) dengan permintaan (demand) yang mendorong naiknya harga Cabe Merah secara berlanjut.

Produksi Cabe Merah di Kalimantan Tengah mengalami fluktuasi, pada tahun 2015 luas panen tercatat sebesar 289 ha, dengan produksi sebanyak 642,6 ton. Sedangkan pada tahun 2016 luas panen terjadi peningkatan menjadi 338 ha, dengan produksi 933 ton (BPS, 2017).

Kota Palangka Raya sebagai ibukota provinsi Kalimantan Tengah memiliki dua sentra produksi Cabe Merah, yaitu di Kelurahan Kalampangan dan di Kelurahan Sei. Gohong. Meski Kota Palangka Raya menghasil kan Cabe Merah di dua wilayah sentra produksi tersebut, namun produksi yang ada masih kekurangan untuk memenuhi permintaan pasar. Berdasarkan data Dinas Pertanian Kota Palangka Raya tahun 2016, produksi Cabe Merah kota Palangka Raya hanya sebesar 252 ton, sementara jumlah permintaan pasar sebanyak 1.040 ton, Sehingga mengalami kekurangan sebanyak 788 ton. Untuk memenuhi kebutuhan Cabe Merah di wilayah Kota Palangka Raya pedagang harus mendatangkan dari Banjarmasin (Kalimantan Selatan) dan dari pulau Jawa.

Sejak tahun 2016, Dinas Pertanian Kota Palangka Raya melakukan program peningkatan produksi Cabe Merah pada empat wilayah yang berpotensi untuk pengembangan tanaman horti kultura, yaitu di Kelurahan Kalampangan, Kelurahan Sei Gohong, Kawasan Sabangau, dan Kelurahan Pager. 
Sejauhmana kegiatan produksi usahatani Cabe Merah di wilayah Kota Palangka Raya dapat memberikan keuntungan atau layak produksi serta seberapa besar pengaruh faktor produksi terhadap produksi Cabe Merah yang diusahakan belum ada data yang tersedia. Oleh karenanya perlu dilakukan penelitian.

\section{Tujuan penelitian}

Tujuan dari penelitian ini adalah :

(1) Menganalisis pengaruh faktor produksi terhadap tingkat produksi usahatani Cabe Merah.

(2) Mengetahui kelayakan usahatani Cabe Merah selama satu kali proses produksi.

\section{METODE PENELITIAN}

\section{Lokasi dan metode penentuan sample}

Metode yang digunakan dalam penelitian ini adalah metode survei. Lokasi penelitian dipilih secara purposive, dilakukan di salah satu sentra produksi Cabe Merah di Kota Palangka Raya yaitu di Kelurahan Sei Gohong Kecamatan Bukit Batu Kota Palangka Raya. Populasi dalam penelitian ini yaitu seluruh petani yang mengusahakan tanaman Cabe Merah di Kelurahan Sei Gohong. Jumlah populasi petani Cabe Merah sebanyak 42 orang petani. Teknik pengambilan sampel menggunakan metode Sample random sampling, dengan rumus Slovin sebagai berikut : $\mathrm{n}=\mathrm{N} /\left(1+\mathrm{Ne}^{2}\right)$, maka jumlah sampel yang diambil sebanyak 30 petani responden.

\section{Analisis Data}

Untuk menjawab tujuan pertama dari penelitian ini yaitu menganalisis pengaruh faktor produksi terhadap tingkat produksi usahatani Cabe Merah, dengan formulasi sebagai berikut :

$\mathbf{Y}=$ bo $\mathbf{X}_{1}{ }^{\mathrm{b} 1} \mathbf{X}_{2}{ }^{\mathrm{b} 2} \mathbf{X}_{3}{ }^{\mathrm{b} 3} \mathbf{X}_{4}{ }^{\mathrm{b} 4} \mathbf{X}_{5}{ }^{\mathrm{b} 5}$

dimana:

$\mathrm{Y}=$ ProduksiCabe Merah (kg/ha)

$\mathrm{X}_{1}=$ Luas lahan $(\mathrm{Ha})$

$\mathrm{X}_{2}=$ Benih $(\mathrm{kg})$

$\mathrm{X}_{3}=$ Pupuk $(\mathrm{kg})$

$\mathrm{X}_{4}=$ Pestisida (ltr)

$\mathrm{X}_{5}=$ Tenaga kerja $(\mathrm{HOK})$

$\mathrm{b}_{0}=$ Koefisien Parameter

Untuk memudahkan dalam pendugaan terhadap persamaan diatas, maka persamaan diubah menjadi bentuk liniear berganda yang dilogaritmakan sehingga menjadi persamaan secara matematis sebagai berikut :

\section{$\operatorname{Ln} Y=\ln a+b_{1} \ln X_{1}+b_{2} \ln X_{2}+$} $b_{3} \ln X_{3}+b_{4} \ln X_{4}+b_{5} \ln X_{5}$

Untuk mengetahui secara statistik apakah faktor yang telah ditetapkan berpengaruh nyata atau tidak terhadap produksi, digunakan uji-t atau uji statistik t-student. Uji-F digunakan untuk mengetahui apakah faktor-faktor produksi tersebut secara bersama-sama berpengaruh nyata terhadap produksi Cabe Merah dengan rumus persamaan sebagai berikut :

(a) Uji t (t-student), untuk meliht pengaruh faktor produksi tersebut secara tunggal (sendiri-sendiri) terhadap produksi.

(b) Uji F (analisis varians), untuk melihat pengaruh secara simultan faktor-faktor produksi tersebut terhadap produksi. 
digunakan analisis persamaan fungsi

Cobb-Douglas (Soekartawi, 2005).

Untuk menjawab tujuan kedua, yaitu mengetahui kelayakan usahatani Cabe Merah selama satu kali proses produksi digunakan analisis Revenue Cost Ratio (RCR) yaitu perbandingan antara Total penerimaan (TR) dengan total biaya (TC). Jika RCR > 1 maka usahatani dikatakan layak untuk diusahakan

\section{HASIL DAN PEMBAHASAN}

\section{Pengaruh faktor produksi terhadap tingkat produksi Cabe Merah}

Hasil analisis terhadap beberapa faktor produksi yang terdiri dari luas lahan $\left(\mathrm{X}_{1}\right)$, benih $\left(\mathrm{X}_{2}\right)$, pupuk $\left(\mathrm{X}_{3}\right)$, pestisida $\left(\mathrm{X}_{4}\right)$ dan tenaga kerja $\left(\mathrm{X}_{5}\right)$ adalah sebagaimana pada Tabel 1 .

Tabel 1. Hasil analisis regresi faktor produksi pada uasahatani Cabe Merah di Kelurahan Sei Gohog Kccamatan Bukit Batu Kota Palangka Raya

\begin{tabular}{cccc}
\hline Variabel & Koefisien Regresi & $\mathbf{F}_{\text {hitung }}$ & Signifikansi \\
\hline Konstanta & 0,846 & 1,848 & 0,071 \\
\hline Luas lahan $\left(\mathrm{X}_{1}\right)$ & 0,329 & 3,165 & $0,003^{* *}$ \\
\hline Benih $\left(\mathrm{X}_{2}\right)$ & 0,150 & 1,765 & $0,042^{*}$ \\
\hline Pupuk $\left(\mathrm{X}_{3}\right)$ & 0,314 & 3,001 & $0,006^{* *}$ \\
\hline Pestisida $\left(\mathrm{X}_{4}\right)$ & $-0,140$ & $-2,054$ & $0,045^{*}$ \\
\hline Tenaga Kerja $\left(\mathrm{X}_{5}\right)$ & $-0,020$ & $-0,453$ & 0,652 \\
\hline Koefisien Determinasi (R2) & $=0,910$ atau 91\% & & \\
$\mathrm{F}_{\text {hitung }}=2,409$ & & \\
$\mathrm{t}_{\text {tabel }}=1,677$ & & \\
Taraf kesalahan $=5 \%$ & & \\
**signifikan pada tingkat kepercayaan 99\% & & \\
*signifikan pada tingkat kepercayaan 95\%. & & \\
Sumber : Hasil pengolahan data, 2017 & &
\end{tabular}

Hasil perhitungan diperoleh bahwa $\mathrm{F}_{\text {hitung }}>\mathrm{F}_{\text {tabel }}(97,513>$ 2,409) dan signifikasi $0,000<$ 0,05, maka Ho ditolak jadi dapat disimpulkan bahwa luas lahan $\left(\mathrm{X}_{1}\right)$, benih $\left(\mathrm{X}_{2}\right)$, pupuk $\left(\mathrm{X}_{3}\right)$ dan pestisida $\left(\mathrm{X}_{4}\right)$ berpengaruh terhadap produksi Cabe Merah, sedangkan tenaga kerja $\left(\mathrm{X}_{5}\right)$ tidak berpengaruh nyata.

\section{Analisis koefisien Regresi (uji t)} Uji t (koefisien regresi parsial) digunaka untuk menegtahui apakah secara parsial luas laha, benih, pupuk, pestisida, dan tenaga kerja berpengaruh secara signifikan terhadap produksi. Melalui uji dua arah dengan taraf kepercayaan $95 \%$, adalah sebagai berikut :

(1) Luas lahan $\left(\mathbf{X}_{1}\right)$, mengguna kan hipotesis:

$\mathrm{H}_{\mathrm{o}}$ : luas lahan tidak ber pengaruh terhadap produksi Cabe Merah.

$\mathrm{H}_{\mathrm{a}}$ : luas lahan berpengaruh terhadap produksi Cabe Merah.

Dasar pengambilan keputusannya :

Dengan tingkat kepercayaan 95\% atau $\alpha=0,05, \mathrm{H}_{\mathrm{o}}$ diterima dan $\mathrm{H}_{\mathrm{a}}$ ditolak jika nilai $t_{\text {hitung }}<$ nilai $t_{\text {tabel }}$ atau jika nilai Sig $>0,05 . \mathrm{H}_{\mathrm{o}}$ ditolak dan $\mathrm{H}_{\mathrm{a}}$ diterima jika nilai $\mathrm{t}_{\text {hitung }}>$ nilai $t_{\text {tabel }}$ atau jika nilai $\operatorname{Sig}<0,05$. 
Hasil perhitungan nilai $t_{\text {hitung }}$ sebesar 3,165 > $t_{\text {tabel }} 1,677$, dimana nilai Sig $<0,05$, artinya luas lahan berpengaruh signifikan terhadap produksi Cabe Merah.

Rata-rata luas lahan petani Cabe Merah 0,15 ha, luas lahan terkecil 0,02 ha, sedang luas lahan terbesar 0,25 ha.

(2) Benih $\left(\mathbf{X}_{2}\right)$, menggunakan hipotesis:

$\mathrm{H}_{1}$ : benih tidak berpengaruh terhadap produksi Cabe Merah.

$\mathrm{H}_{\mathrm{a}}$ : benih berpengaruh terhadap produksi Cabe Merah.

Hasil perhitungan nilai $t_{\text {hitung }}$ sebesar $1,765>t_{\text {tabel }} 1,677$, dimana nilai Sig $<0,05$, artinya benih berpengaruh signifikan terhadap produksi Cabe Merah.

Jenis benih Cabe Merah yang digunakan adalah merek "Wibawa". Rata-rata penggunaan benih Cabe Merah oleh petani sebanyak 2,3 bungkus per usahatani atau rata-rata 15,3 bungkus per ha, terkecil 1 bungkus per usahatani, sedang terbanyak 4 bungkus per usahatani. Berat satu bungkus benih 0,2 gram atau rata-rata penggunaan benih sebanyak 75 gram per ha. Harga benih merek Wibawa seharga Rp 125.000 per bungkus.

(3) Pupuk ( $\left.\mathbf{X}_{\mathbf{3}}\right)$, menggunakan hipotesis:

$\mathrm{H}_{1}$ : pupuk tidak berpengaruh terhadap produksi Cabe Merah.

$\mathrm{H}_{\mathrm{a}}$ : pupuk berpengaruh terhadap produksi Cabe Merah.

Hasil perhitungan nilai $t_{\text {hitung }}$ sebesar 3,001 $>\mathrm{t}_{\text {tabel }} 1,677$, dimana nilai Sig $<0,05$, artinya pupuk berpengaruh signifikan terhadap produksi Cabe Merah.
Jenis pupuk yang digunakan petani terdiri dari pupuk Urea, TP, $\mathrm{KCl}$ dan pupuk kandang. Rata-rata pupuk yang digunakan sebanyak 233 $\mathrm{kg} / \mathrm{Ha}$, TSP sebanyak $367 \mathrm{~kg} / \mathrm{Ha}$, $\mathrm{KCl}$ sebanyak $367 \mathrm{~kg} / \mathrm{Ha}$, dan pupuk kandang sebanyak 1.967 sak/Ha (1 $\mathrm{sak}=25 \mathrm{~kg}$ ). Selain pupuk, untuk mengatasi keasaman tanah petani menggunakan Kapur Dolomit ratarata sebanyak 137 sak/Ha.

(4)Pestisida $\left(\mathbf{X}_{4}\right)$, menggunakan hipotesis:

$\mathrm{H}_{1}$ : pestisida tidak berpengaruh terhadap produksi Cabe Merah.

$\mathrm{H}_{\mathrm{a}}$ : pestisida berpengaruh ter hadap produksi Cabe Merah.

Hasil perhitungan nilai $t_{\text {hitung }}$ sebesar $-2,054<t_{\text {tabel }} 1,677$, dimana nilai Sig $0,045<0,05$, maka $\mathrm{H}_{\mathrm{a}}$ diterima artinya pestisida berpengaruh terhadap produksi Cabe Merah.

Jenis pestisida yang digunakan terdiri dari Roundup Biosorb 486 L, Polaris, dan Furadan 3 G. Rata-rata volume pestisida yang digunakan: Round-up 2,20 liter/Ha, Polaris 1,65 liter $/ \mathrm{Ha}$, dan Furadan 1,3 kg/Ha.

(5) Tenaga kerja $\left(\mathbf{X}_{5}\right)$, mengguna kan hipotesis:

$\mathrm{H}_{1}$ : tenaga kerja tidak ber pengaruh terhadap produksi Cabe Merah.

$\mathrm{H}_{\mathrm{a}}$ : tenaga kerja berpengaruh pada hasil Cabe Merah.

Hasil perhitungan nilai $t_{\text {hitung }}$ sebesar $-0,235<\mathrm{t}_{\text {tabel }} 1,677$, dimana nilai Sig $0,816>0,05$, maka $\mathrm{H}_{\mathrm{a}}$ ditolak artinya tenaga kerja tidak berpengaruh terhadap produksi Cabe Merah.

Rata-rata curahan tenaga kerja dalam keluarga sebanyak 58,4 HKO/Ha, tenaga kerja luar keluarga sebanyak $12,0 \mathrm{HKO} / \mathrm{Ha}$. Besarnya upah tenaga kerja rata-rata Rp 70.000 per HKO. 


\section{Kelayakan Usahatani Cabe Merah}

Hasil perhitungan kelayakan usahatani dengan menggunakan kriteia Revenue Cost Ratio (RCR) diperoleh nilai sebesar 3,2. Hal ini berarti setiap pengeluaran biaya untuk usahatani Cabe Merah sebesar Rp $\quad 1.000$ akan menghasilkan penerimaan sebesar Rp 3.200. RCR $>1$, sehingga usahatani Cabe Merah di Kelurahan Sei Gohong Kecamatan Bukit Batu Kota Palangka Raya adalah layak atau menguntungkan untuk diusahakan.
Secara rinci nilai penrimaan, biaya dan RCR sebagaimana pada Tabel 2.

Dari Tabel 2 diketahui Total penerimaan (TR) usahatani Cabe Merah sebesar Rp 266.346.667 per $\mathrm{Ha}$, total biaya sebesar Rp 98.552.147 per Ha. Total pendapatan Cabe Merah selama satu kali proses produksi (3 bulan) sebesar 195.047.854 per Ha. Keuntungan sebesar Rp 167.794.520 per Ha. Rata-rata produksi Cabe Merah yang dihasilkan petani sebanyak 12.107 $\mathrm{Kg}$ per Ha.

Tabel 2. Analisis Usahatani Cabe Merah di Kelurahan Sei Gohong Kecamatan Bukit Batu Kota Palangka Raya tahun 2017

\begin{tabular}{|c|c|c|c|}
\hline Uraian & Satuan & $\begin{array}{c}\text { Rata-rata } \\
\text { Nilai } \\
\text { (per usahatani) } \\
\end{array}$ & $\begin{array}{c}\text { Rata-rata } \\
\text { Nilai } \\
\text { (per Hektar) } \\
\end{array}$ \\
\hline Harga jual & $\mathrm{Rp} / \mathrm{kg}$ & 22.000 & 22.000 \\
\hline Total produksi (TP) & $\mathrm{Kg}$ & 1.816 & 12.107 \\
\hline Biaya Eksplisit : & $\mathrm{Rp}$ & 10.694 .822 & 71.298 .813 \\
\hline - Biaya Variabel (VC) & $\mathrm{Rp}$ & 10.298 .600 & 68.657 .333 \\
\hline - Biaya Tetap (FC) & $\mathrm{Rp}$ & 396.222 & 2.641 .480 \\
\hline Biaya Implisit (TKDK) & $\mathrm{Rp}$ & 4.088 .000 & 27.253 .333 \\
\hline Tatal Biaya (TC) & $\mathrm{Rp}$ & 14.782 .822 & 98.552 .147 \\
\hline Total penerimaan (TR) & $\mathrm{Rp}$ & 38.952 .000 & 266.346 .667 \\
\hline Total pendapatan (TI) & $\mathrm{Rp}$ & 28.257 .178 & 195.047 .854 \\
\hline $\operatorname{Keuntungan}(\pi)$ & $\mathrm{Rp}$ & 25.169 .178 & 167.794 .520 \\
\hline
\end{tabular}

Sumber; hasil pengolahan data, 2017

Menurut petani di Kelurahan Sei Gohong bahwa saat yang tepat untuk menanam Cabe Merah adalah pada bulan Juli-September yaitu pada bulan kering atau musim kemarau. Hal ini untuk menghindari resiko serangan penyakit cendewan maupun bakteri yang sering menyerang tanaman Cabe Merah di musim basah.

Berdasarkan pengalaman petani diketahui bahwa harga Cabe Merah tertinggi di Kota Palangka Raya biasanya terjadi pada bulan Desember hingga bulan Januari. Hal ini terjadi karena pada bulan tersebut permintaan Cabe Merah karena terkait dengan situasi Lebaran, Natal dan menjelang Tahun Baru.

Sementara pada bulan Desember biasanya gelombang laut tinggi mencapai 2 meter, pelayaran terganggu yang berakibat pasokan Cabe Merah dari pulau Jawa berkurang (BI Palangka Raya, 2012). 


\section{KESIMPULAN DAN SARAN}

\section{Kesimpulan}

Berdasarkan hasil penelitian ini disimpulkan sebagai berikut :

(1) Pada proses produksi usahatani Cabe Merah di Kelurahan Sei Gohong Kecamatan Bukit Batu Kota Palangka Raya diketahui bahwa faktor produksi luas lahan, benih, pupuk, dan pestisida berpengaruh signifikan terhadap produksi Cabe Merah. Sedangkan faktor produksi tenaga kerja tidak berpengaruh terhadap produksi Cabe Merah. Jumlah curahan tenaga kerja sebanyak 70,4 HKO per Ha sudah optimal. Penambahan tenaga kerja pada luasan lahan yang sama akan menambah beban biaya.

(2) Total penerimaan usahatani Cabe Merah di Kelurahan Sei Gohong Kecamatan Bukit Batu Kota Palangka Raya sebesar Rp 39.952.000 per Ha, total biaya sebesar Rp 14.782.822 per Ha. Total pendapatan Cabe Merah selama satu satu kali proses produksi (selama 3 bulan) sebesar 25.169.178 per Ha. Hasil peritungan analisis kelayakan diketahui nilai RCR sebesar 3,2 dimana RCR > 1. Hal ini berarti usahatani Cabe Merah layak diusahakan.

\section{Saran}

Dari hasil penelitian ini disarankan kepada:

(1) Petani diharapkan untuk usahatani Cabe Merah hendaknya terus dilanjutkan dengan cara meningkatkan produksi melalui perluasan lahan dan penggunaan input benih, pupuk, dan pestisida yang optimal.

(2) Usahatani Cabe merah layak diusahakan. Penetapan waktu tanam hendaknya mengacu kepada waktu pemasaran yang tepat, yaitu pada saat panen harga jualnya tinggi.
Umumnya harga Cabe Merah berada di atas harga rata-rata terjadi pada Oktober, November, dan Desember.

(3) Kepada pihak pemerintah provinsi/kota hendaknya terus melakukan pembinaan dan bantuan sarana produksi serta pemasaran kepada petani Cabe Merah guna meningkatkan kuantitas dan kualitas produksi serta jaminan harga untuk peningkatan pendapatan dan kesejahteraan petani.

\section{DAFTAR PUSTAKA}

Bank Indonesia Palangka Raya, 2012. Laporan penelitian Penentuan Harga Pokok Produksi Dan Model Ketahaanan Pangan Cabai Merah Di Kota Palangka Raya.

Badan Pusat Statistik. 2017. Kalimantan Tengah Dalam Angka 2016. BPS Palangka Raya.

Badan Pusat Statistik. 2017. Kota Palangka Raya Dalam Angka 2016. BPS Palangka Raya.

Soekartawi. 2004. Teori Ekonomi Produksi Dengan Pokok Bahasan Analisis Fungsi CobbDouglas. Raja Grafindo Persada. Jakarta.

Soekartawi. 2005. Analisis Usahatani . UI. Jakarta. 